\title{
ANL/DIS/CP- -84532
}

KEEPING THE PEACE GREEN:

INTEGRATING ARMS CONTROL AND ENVIRONMENTAL PROTECTION

Presented to the:

University of Pennsylvania School of Law

Temple University School of Law

October 21, 1994

Presented by:

Edward A. Tanzman

Manager, Economics and Law Section

Argonne National Laboratory

9700 South Cass Avenue

Argonne, IL 60439-4832

(708) $252-3263$
Professor Barry Kellman

DePaul University College of Law

25 East Jackson Boulevard

Chicago, IL 60604

(312) 362-5258

Work supported by Argonne National Laboratory through contract DNA001-90-C-0177. The opinions expressed herein are those of the authors and not necessarily those of Argonne National Laboratory or its sponsors.

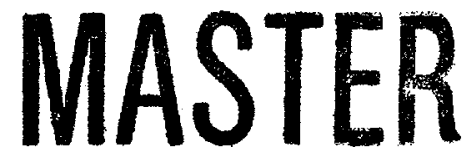




\section{DISCLAIMER}

Portions of this document may be illegible in electronic image products. Images are produced from the best available original document. 


\section{KEEPING THE PEACE GREEN: INTEGRATING ARMS CONTROL AND ENVIRONMENTAL PROTECTION}

\section{INTRODUCTION}

Good afternoon. This talk is about how to avoid turning swords into Superfund sites. The problem we address is the potential conflict between the desire to take advantage of the greater international security brought by the end of the Cold War by entering arms control agreements requiring various military weapons to be dismantled, and the desire to avoid further degrading the environment in the process of destroying them. We will use as an illustration of these issues the Chemical Weapons Convention (CWC) ${ }^{1}$, which is intended to cause the destruction of all chemical weapons in the world. First, we will provide a brief overview of the $\mathrm{CWC}$, then we will focus in on its environmental provisions, and, finally, we will discuss potential conflicts with United States law and how they might be resolved.

\section{OVERVIEW OF THE CHEMICAL WEAPONS CONVENTION}

The CWC is the most comprehensive multilateral arms control treaty in world history. Not only does the Convention ban the wartime use of chemical weapons, which is already provided for in another treaty, but it also prohibits the acquisition or maintenance of a capability to do so. Furthermore, this treaty contains the most extensive verification system every devised, in effect introducing the concept of law enforcement to multilateral arms control in several forms. These include broad national reporting requirements with respect to legitimate industrial chemicals that could be made into chemical weapons, export controls to restrict their transfer to non-signatories, and verification inspections by a new international organization of both the facilities that possess these chemicals and of any other location or facility that a State Party suspects may be involved in noncompliance.

The heart of the Convention, of course, is to obliterate existing chemical weapons and their production facilities. Articles IV and V of the Convention require, first, declaration, and, within ten years after the Convention enters into force, destruction of all chemical weapons or chemical weapons production facilities that a State Party owns or possesses, or that are located under its jurisdiction or control. Extension of the ten-year destruction deadline is available under some circumstances. Each State Party must bear these destruction costs, with the proviso that chemical weapons in one State Party that are owned or possessed by another State Party are the primary responsibility of the State Party owning or possessing them. Chemical weapons production facilities can, under certain circumstances, be converted temporarily to destruction facilities or permanently to other uses not prohibited under the Convention.

1. Draft Convention on the Prohibition of the Development, Production, Stockpiling and Use of Chemical Weapons and on Their Destruction, U.N. Dot $A / 47 / 27$ (23 September 1992) [hereinafter CWC]. This version of the CWC was signed by 130 nations in Paris, France, on January 13, 1993. As of April 1, 1994, 157 nations have signed the CWC. 


\section{CONVENTION PROVISIONS FOR SAFETY AND ENVIRONMENTAL PROTECTION}

Among its many unique and precedent-setting provisions, the CWC includes important requirements for States Parties to protect the public safety and the environment in the course of carrying out the treaty. The Convention's safety and environmental policy is comprised of several key provisions. The central reference to these protections is contained among the national implementation measures that each State Party is required to adopt. It states:

Each State Party, during the implementation of its obligations under this Convention, shall assign the highest priority to ensuring the safety of people and to protecting the environment, and shall cooperate as appropriate with other States Parties in this regard. ${ }^{2}$

This language is repeated in essentially the same form in the specific articles governing destruction of chemical weapons and former chemical weapons production facilities, with the added requirement that these activities be carried out by each State Party "in accordance with its national standards for safety and emissions." 3 In addition to these affirmative safety and environmental protection responsibilities, the Convention specifically prohibits the chemical weapons destruction methods of "dumping in any body of water, land burial or open-pit burning." 4

States Parties are entitled to determine how they will "assign the highest priority" to safety and environmental protection as they destroy their chemical weapons and former production facilities, and during verification activities. It is difficult to see a practical basis in the Convention itself for States Parties or the Organization for the Prohibition of Chemical Weapons ${ }^{5}$ (OPCW), the body responsible for administering the Convention, to compel a particular destruction method At most, this language gives States Parties or the OPCW the right to raise questions with respect to the ecological soundness of the destruction methods that are chosen.

The priority of protecting safety and the environment is not superior to the weapons destruction obligation. These provisions exist only in the context of the general obligation committing each State Party to "destroy chemical weapons it owns or possesses, or that are located in any place under its

\section{Id. art. VII, $\uparrow 3$.}

3. Id. art. IV, I 10 states that "[e]ach State Party, during transportation, sampling, storage, and destruction of chemical weapons, shall assign the highest priority to ensuring the safety of people and to protecting the environment. Each State Party shall transport, sample, store and destroy chemical weapons in accordance with its national standards for safety and emissions." Art. V, I 11 imposes the same requirements on destroying chemical weapons production facilities.

4. Id. Verification Annex, Part IV (A), I13. However, since this provision is located in an Annex to the Convention -- where reservations are permitted -- it would be possible for a State Party to ratify the Convention while exempting itself from these restrictions. Id. art. XXII. Nevertheless, singling out these undesirable destruction methods and imposing on each State Party the burden of specifically including a reservation in order to retain them as options can be expected to make it more politically difficult to use them. Furthermore, paragraph 32 obligates a State Party to provide to the Technical Secretariat the safety plans and the environmental permits that have been obtained for each of its chemical weapons destruction facilities.

5. See generally id. note 1 , art. VIII. 
jurisdiction or control." 6 In other words, the Convention contains no textual basis for concluding that a State Party can fail to destroy its chemical weapons within ten years because its safety or environmental laws prohibit it from doing so. However, perhaps these provisions can be read to furnish a basis for States Parties that are unable to comply with the Convention's requirement to destroy all chemical weapons within ten years after entry into force to request from the Conference of the States Parties of the OPCW an extension in the destruction deadline of up to five years. ${ }^{7}$ This may be of particular concern to the United States because the Russian Federation has encountered significant domestic resistance to previous chemical weapons destruction strategies because of fears for safety and environmental protection.

The Convention's safety and environmental protection provisions could lead to several other noteworthy consequences as it is implemented. First, this language could affect those States Parties, like the Peoples Republic of China, which are the location of chemical weapons abandoned by others, in this

case allegedly by the Government of Japan after World War II. ${ }^{8}$ The Convention's requirements could provide those in China's position the leverage to negotiate for adoption of the most ecologically sound destruction method as the State Party largely responsible for destroying the weapons (in this case, Japan) carries out its obligations in this regard. ${ }^{9}$ Second, these provisions create a textual basis for domestic organizations, such as public interest groups, to urge adoption by States Parties of the safest and most environmentally protective destruction and verification methods available. Third, the Convention's environmental policies give States Parties the right to request assistance from other States Parties in order to comply with the Convention's safety and environmental requirements. This is especially important to destruction of the Russian chemical weapons stockpile, where such assistance has already been requested from the United States.

\section{EFFECTS ON DESTRUCTION OF UNITED STATES CHEMICAL WEAPONS}

The application of United States environmental law to destroying this nation's chemical weapons stockpile is one fascinating illustration of how the Convention's safety and environmental policy might operate. Since World War I, the United States has stockpiled both unitary and binary chemical weapons at eight domestic locations. The United States unitary stockpile consists chiefly of three types of chemical weapons -- mustard, GB, and VX. ${ }^{10}$ Mustard is a blister agent, meaning that it creates chemical burns and can be lethal if inhaled. GB and VX are nerve agents that both destroy the nervous system, with GB designed primarily to kill following inhalation and VX to kill upon skin contact. These agents are stored in several different ways, including in bulk tanks, in spray tanks, and in various munitions such as bombs, rockets, artillery projectiles, and mines. The agent that is weaponized is particularly difficult to

6. Id. art. I, \&2.

7. See id. pt. IV(A), C(24)-(28).

8. Doty, The Challenge of Destroying Chemical Weapons, ARMS CONTROL TODAY, Oct. 1992, at 29.

9. See CWC, supra note 1, Annex on Verification and Implementation, pt. IV(B).

10. See generally President's Message to Congress Transmitting the Environmental Review of the Chemical Weapons Convention, $\$ 2.1$, reprinted in Cong. Rec. S2168 (daily ed. March 1, 1994). 
destroy because the weapons are themselves dangerous to handle, with some in an unstable condition. The more modern binary stockpile is much safer to handle and destroy because each weapon consists of two separate components of nerve agent that are stored in different states, which cannot become chemical agent until they are purposely combined at the time of use. ${ }^{11}$

The United States is already under a domestic deadline to destroy its unitary chemical weapons, pursuant to a federal statute requiring destruction to be completed by December $31,2004,{ }^{12}$ in compliance with all federal and state environmental laws that apply. The estimated life cycle cost is more than $\$ 8$ billion. ${ }^{13}$ This initiative was undertaken by the U.S. Army because of growing concern that the unitary weapons, many of which date back to the 1950 s or earlier, are increasingly dangerous to store as they deteriorate with age. An additional $\$ 1.1$ billion will be needed to destroy the binary weapons, former chemical weapons production facilities, and other items covered by the Convention. ${ }^{14}$

The massive unitary weapons destruction program has been the subject of risk and environmental studies that are controversial because, together, they justify high temperature incineration as the preferred weapons destruction method. This process includes a robotic system to punch and drain the munitions and tanks, a separate high temperature furnace to destroy the so-called energetics and propellants from the drained munitions, and three additional furnaces to break down the nerve agent that has been collected as well as the residues that may remain on the drained munitions and tanks. ${ }^{15}$

Some have argued that incineration presents too great a risk of releasing deadly pollutants during destruction due to incomplete combustion or other inevitable malfunctions. ${ }^{16}$ However, a committee of the National Research Council has concluded that no alternate technology on the horizon appears to justify the even-greater risk of a catastrophic release of agent that would accrue while waiting for a better method to be perfected. ${ }^{17}$ Nevertheless, it appears that destruction of chemical weapons in the United

11. See id. § 2.2.2.1.

12. Defense Authorization Act of 1993, Public L. No. 102-484, § 171, Stat. (1993).

13. See M. Owen, Acting Assistant Secretary of the Army (Installations, Logistics and Environment), Testimony on the Chemical Demilitarization Program before the Subcommittee on Nuclear Deterrence, Arms Control, and Defense Intelligence of the U.S. Senate Committee on Armed Services, May 26, 1993, at 19.

14. Program Manager for Non-StockPile ChemiCal Materiel, Non-StockPile Chemical Materiel PROGRAM: SURVEY AND ANALYSIS REPORT at 9-1 (1993).

15. See President's Message to Congress Transmitting the Environmental Review of the Chemical Weapons Convention, $\$ 2.1$, reprinted in Cong. Rec. S2168 (daily ed. March 1, 1994).

16. See, e.g., P. Costner, Chemical Weapons Demilitarization and Disposal: Johnston Atoll Chemical Disposal System, GB and VX Campaigns, at 1 (Paper presented at the Moscon '93 Conference, Moscow, Russian Federation, May 12, 1993).

17. National Research Council Committee on Review and Evaluation of the ARmy Chemical StockPile Disposal Program, et aL., Recommendations for the Disposal of Chemical AgENTS AND MuNITIONS, at 121 (1994). 
States will continue to be politically sensitive, ${ }^{18}$ and it is fair to expect local opposition to incineration from some residents of some of the eight communities where the weapons destruction facilities are planned.

The Convention undoubtedly will affect this debate. The Convention's ten-year weapons destruction deadline adds an additional legal reason for proceeding without delay. ${ }^{19}$ Disputes that develop about weapons destruction will be resolved based not only on domestic safety and environmental values, but on the place these considerations occupy in the Convention and on international law.

One can imagine different hypothetical scenarios where these issues might be litigated. A likely arena for conflict between the Convention and domestic safety and environmental concerns would be an impossibly strict state environmental statute. For example, the Commonwealth of Kentucky, which has enacted a statute requiring the Army to prove that no alternative method of destruction "could be developed" that poses less risk, could refuse to issue a permit under its Clean Air Act state program for a chemical agent destruction facility at the Blue Grass Army Depot. ${ }^{20}$ Alternatively, a citizens group could sue to enjoin incinerator operation, alleging, inter alia, that the United States has failed to "assign the highest priority" to safety as required by the Convention.

But it is doubtful that either of these imaginary suits would succeed. It is unlikely that a state law would be permitted by a federal court to stand in the way of incineration in the face of an Executive Branch determination that high temperature incineration is needed to meet the Convention's destruction deadline. ${ }^{21}$ A citizens group claiming that incineration violates the Convention would stand even less of a chance because the language in the Convention requiring assignment of the highest priority to safety and environmental protection does not appear to create domestic citizens standing.

Nevertheless, the existence of some community concern about chemical weapons destruction is real. If a fight over chemical weapons destruction develops in some areas, it could be a bitter one that is better avoided by careful federal consideration of state and local safety and environmental apprehensions. $^{22}$ The fact that the federal government is about to assume additional, international responsibilities for compliance under the CWC should not in my opinion become an excuse for indifference to local worries. Fortunately, the federal government appears currently to be on a path intended to address these concerns.

18. See Doty, The Challenge of Destroying Chemical Weapons, ARMS CONTROL TODAY, Oct. 1992, at 26.

19. See President's Message to Congress Transmitting the Environmental Review of the Chemical Weapons Convention, $\$ 4.2 .1$, reprinted in Cong. Rec. S2168 (daily ed. March 1, 1994).

20. Doty, The Challenge of Destroying Chemical Weapons, ARMS CONTROL TODAY, Oct. 1992, at 26.

21. See D. Gualtieri, B. Kellman, R. Haffenden, E. Tanzman, A. Loeb, and M. Anders, Chemical Weapons Inspection of Private Facilities -- Application of United States Environmental and Safety Laws, 49-51 (DNA-TR-93$70,1993)$.

22. "Cooperation of executive and police officials of states and municipalities appears . . clearly desirable and helpful. . . . There are certainly no obstacles under the laws of the United States to voluntary cooperation between states and municipalities and an international arms inspectorate." L. HENKIN, ARMS CONTROL AND INSPECTION IN AMERICAN LAW 102 (1958). 


\section{CONCLUSIONS}

As exemplified by the CWC, arms control treaties not only promotes arms control, they challenge the legal community as well. The Convention's policies regarding safety and environmental protection will affect the relationship between international obligations and domestic law in novel ways. To the extent it becomes a precedent for other agreements - and there is good reason to believe that this is just what is going to happen - careful planning that involves attorneys can help avoid unnecessary and destructive conflicts over the relative importance of the equally desirable goals of arms control and ecological responsibility.

\section{DISCLAIMER}

This report was prepared as an account of work sponsored by an agency of the United States Government. Neither the United States Government nor any agency thereof, nor any of their employees, makes any warranty, express or implied, or assumes any legal liability or responsibility for the accuracy, completeness, or usefulness of any information, apparatus, product, or process disclosed, or represents that its use would not infringe privately owned rights. Reference herein to any specific commercial product, process, or service by trade name, trademark, manufacturer, or otherwise does not necessarily constitute or imply its endorsement, recommendation, or favoring by the United States Government or any agency thereof. The views and opinions of authors expressed herein do not necessarily state or reflect those of the United States Government or any agency thereof. 